\title{
神居古潭帯に分布する蛇紋岩の不攪乱状態および 再構成粘性土試料の力学特性

\author{
Mechanical properties of undisturbed and reconstituted serpentinite \\ originated from the Kamuikotan belt in Hokkaido
}

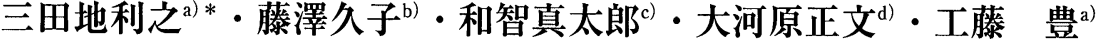 \\ Toshiyuki MITACHI, Hisako FUJISAWA, Shintaro WACHI, Masafumi OKAWARA and Yutaka KUDOH
}

\begin{abstract}
Various laboratory tests such as triaxial test, reversal direct box shear test, swelling pressure test, slaking test were carried out to investigate the mechanical properties of serpentinite using the undisturbed and reconstituted samples originated from the Kamuikotan belt in Hokkaido. From the test results, it was concluded as follows.

The residual angle of shearing resistance $\phi^{\prime}{ }^{\prime}$ as well as the peak angle of shearing resistance $\phi^{\prime}{ }_{\phi}$ were unexpectedly large by showing $\phi^{\prime}{ }_{r}=27 \sim 28^{\circ}$ and $\phi_{p}^{\prime}=31 \pm 2^{\circ}$ irrespective of the state of undisturbed or reconstituted. But the undrained strength of the reconstituted specimen was less than one fourth of the undisturbed one due to marked difference of dilatancy characteristics of those specimens. The angle of shearing resistance between the pre-existing foliated flakes of serpentinite exhibited $6.5^{\circ}$ at minimum.

Key words : triaxial compression test, reversal direct box shear test, residual state angle of shear resistance, swelling pressure, slaking

和文要旨

北海道神居古潭带で採取された蛇紋岩の不攪乱状態および再構成の試料について, 三軸圧縮試験，繰返し一面せん断試験，膨潤 圧試験，スレーキング試験などの各種力学試験を実施した。試験の結果，蛇紋岩のピークせん断抵抗角 $\phi^{\prime}{ }_{p}$ は不擋乱，再構成によら ず, $31 \pm 2^{\circ}$ 程度の值をとり, 残留状態のせん断抵抗角 $\phi^{\prime}{ }^{\prime}$ は $27 \sim 28^{\circ}$ と予想外に大きい。しかし, 蛇紋岩粘性土の非排水せん断強度 はダイレタンシー特性の違いから，不翼乱蛇紋岩の 4 分の 1 以下と大幅に低下する。また，予め葉片に沿って二分し，試料の表面 を磨いた状態での試験結果から得られた葉片に沿う最小のせん断抵抗角は $6.5^{\circ}$ を示した。

キーワード：三軸圧縮試験, 繰返し一面せん断試験, 残留状態せん断抵抗角, 膨潤圧, スレーキング
\end{abstract}

\section{1.はじめに}

北海道を南北に縦断する神居古潭帯に点々と分布する 蛇紋岩地域は日本有数のものであり，過去に切り土やト ンネル施工中の地すべりや崩壊，強大な土圧の発生等の 難工事を強いられてきた1)。

蛇紋岩体の中心部には比較的堅硬な塊状の蛇紋岩が存 在するが，風化過程からみると中心から外れるに従い葉 片状となり，更に他の地質体との境界部では粘土状へと 変化して分布することが知られている ${ }^{2)}$ 。また, 塊状蛇 紋岩も応力解放や水の影響により容易に風化し, 葉片状, 粘土状となり得る。これらの地質学的検討から蛇紋岩体 は非常に脆弱な岩体であるとされ，鉱物学的・化学的特 性や地質学的特徴に関しては多くの研究がなされてい

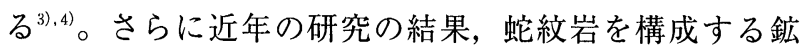
物, タルクやスメクタイト等の存在がその強度特性およ び強度低下に大きな影響を及ぼしていると考えられてい る。工学的観点からの工事報告もなされてはいるが(1),5),6),

* 連絡著者/corresponding author

a) 北海道大学大学院工学研究科

Graduate School of Eng. Hokkaido Univ.

T060-8628 北海道札帨市北区北13条西 8 丁目

Kita-13 Nishi-8, Sapporo, 060-8628, Japan

b) 日本工営(制)

Nippon Koei Co., Ltd.

前田建設工業(筱)

Maeda Corporation

d) 岩手大学工学部建設環境工学科

Iwate Univ.
力学的研究は比較的少ない。また, 既往の力学的研究で は風化が進んで粘土化した蛇紋岩風化粘性土2),7),8),9)，あ るいは蛇紋岩を粉砕して細粒化したもの ${ }^{10), 11)}$ 用いてお り，不摚乱状態で採取された蛇紋岩を用いた研究ではな く，また蛇紋岩を不擋乱状態で三軸試験に供することは 困難であるとされてきた。したがって，従来の力学的研 究では，蛇紋岩そのものの強度特性を把握したとは言い 難い。

北海道神居古潭帯に位置する勇払郡占冠村の地すべり 地帯を通る道路トンネル坑口付近の地質調査に際して, 蛇紋岩の不擋乱試料の採取が試みられた。本研究ではこ の不攪乱試料を用いて，圧密非排水三軸圧縮試験と繰返 し定圧一面せん断試験を行い, 試験後の試料を粉砕して 再構成した供試体についての試験結果と比較し，自然状 態の蛇紋岩の力学特性を明らかにしょうとするものであ る。加えて, X線回折による鉱物分析，スメクタイトの 定量分析のほか不擋乱蛇紋岩の葉片に沿う一面せん断試 験，スレーキング試験および圧密容器を利用した膨潤圧 試験の結果についても報告する。

\section{2. 構成鉱物}

$2.1 X$ 線回折による分析結果

蛇紋石の主要な鉱物はアンティゴライト, クリソタイ 
ル，リザーダイトであるとされるが，蛇紋岩は一般に蛇 紋石だけで構成されているわけではなく，その他にタル ク，カルサイト，クロライト，スメクタイトといった鉱 物が含まれている場合のあることが知られている。近年 の研究の結果, これらタルクやスメクタイト等が多く含 まれる蛇紋岩のせん断抵抗角は，含有量の少ない蛇紋岩 のせん断抵抗角よりも小さく，地すべりなどの問題を引 き起こしやすいのではないかと考えられている7。

そこで構成鉱物の同定のためにX線回折を行った。試 験は粉末法で行い，試料は 2 種類で，異なる 2 箇所の ボーリング孔からの試料である。試料 I は蛇紋岩を粉砕 し，試料I は粉砕せずに自然に崩れた試料を $74 \mu \mathrm{m} ふ る$ いに通した試料である。

回折図を図ー 1 に示す。図より試料 I および試料 II と も $12^{\circ}$ と $24^{\circ}$ に明瞭なピークが見られることから蛇紋石で あるクリソタイル，リザーダイトが含まれていることが わかる。また，試料 II では $6^{\circ}$ 付近と $19^{\circ}$ 付近にピークが 見られ，これは膨润性の粘土鉱物（スメクタイトあるい はクロライト）とタルクと考えられる。

\section{2 スメクタイトの定量分析}

スメクタイトの含有割合を調べるためにメチレンブ ルー吸着法（MB法）を行った。X線回折と同様， $74 \mu \mathrm{m}$ ふるい通過試料を用いた。その結果スメクタイト含有量 は約 $3 \sim 26 \%$ と幅広く, 同地带の蛇紋岩でも含有割合は かなり異なることがわかった。

\section{3．圧密非排水三軸圧縮試験における強度特性}

試料は, 軟岩用ダブルコアチューブを用い，ミスト ボーリングによって採取された葉片状蛇紋岩である。採 取深度は地表面下 $7.0 \mathrm{~m} \sim 20.5 \mathrm{~m}$ の範囲である。試料の 側面は淡緑あるいは暗緑色塊状で滑らかであり，断面は 暗緑色の葉片状であるものが多く，そのほとんどが蛇紋 石を主成分鉱物とする蛇紋岩であるが，若干の方解石， 滑石を含むもの，また膨潤性粘土鉱物を多く含むものも あった。供試体の成形にあたっては，試験に支障をきた

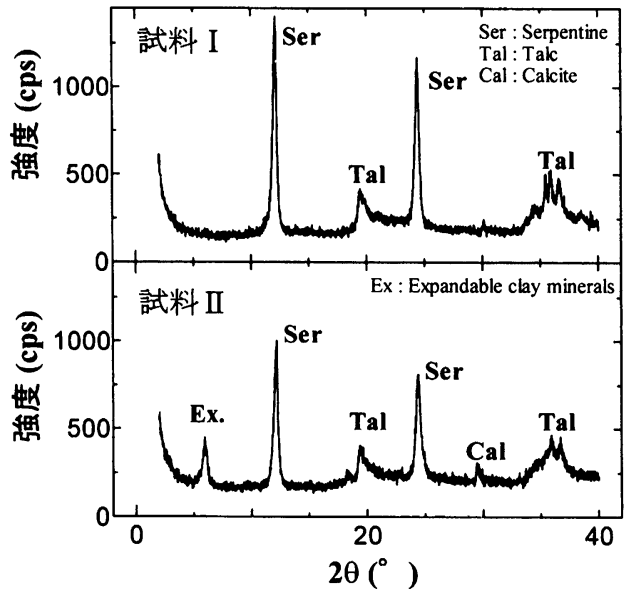

図一 1 X線回折図

Fig. 1 Results of X-ray diffraction analysis
すような大きなクラックの見られない部分を使用するよ うにした。

\section{1 実験概要}

試験に用いた試料は，大部分が非常に脆く剥離性の著 しい葉片状であったため，供試体の作製には細心の注意 を払い，アクリル製のコアチューブに入ったまま，所定 の高さ $(125 \mathrm{~mm})$ に切断し，チューブを外してそのま まの直径（83mm）で試験に供した ${ }^{12) .13)}$ 。表一 1 に試料 の初期状態と実験条件を示す。

実験は(1)原位置の土被り圧相当の応力（ $\mathrm{p}_{\mathrm{c}}^{\prime}$ ) まで等方 圧密(2)その後所定の応力 $\left(\mathrm{p}_{\mathrm{s}}^{\prime}\right.$ ) まで除荷（Rの記号を付 しており，たとえばp'的 $1 / 2$ まで除荷した場合CR 2 U) (3)せん断の 3 過程と排水条件UU, CU, CDの組み合わ せの違いによる 5 種類の三軸圧縮試験である。CRU試 験については除荷の程度を 3 種類に変えている。

圧密・膨張の打ち切り基準として 3 t法を適用し, 排 水・非排水せん断時のひずみ速度はそれぞれ0.002\%/ $\min$ および $0.1 \% / \mathrm{min} て ゙ ，$ 排水試験（CD，CRD）以外は いずれも間隙水圧の測定を伴う試験である。なお，初期 状態の飽和度は表ー 1 に示すように試料によってばらつ きがあるが，三軸試験の圧密過程開始時点からすべての 供試体について $200 \mathrm{kPa}$ の背圧を載荷している。圧密お よび膨張に要した時間はそれぞれ250〜400分および700 〜1000分であった。

\section{2 試験結果および考察}

(1) 応力ーひずみ挙動

図-2〜 5 はCU及びCRU試験の主応力差 $\mathrm{q}\left(=\sigma_{\mathrm{a}}^{\prime}-\right.$ $\left.\sigma_{\mathrm{r}}^{\prime}\right)$ 軸ひずみ $\varepsilon_{\mathrm{a}}$ 関係を示したものであり，図- 3 以降 では圧密・䐍張時の応力条件の違いによって分けて表示 した。図ー 3 はCU試験における結果である。等方圧密 圧力と共に，非排水強度が増大していることがわかる。 軸ひずみ15\%時点で試験を終了することを基準としたが， CU 3 試験ではロードセルの限界によりやむなく実験を 中止し, CU 2 試験においては供試体にせん断面が現れ, メンブレンの限界であると判断し実験を終了した。CU 2 の試料はカルサイトとタルクを含んでいたが，一般に 強度の低いとされるタルクの影響は明確に現れていない ようである。

表一 1 実験条件（三軸圧縮試験）

Table 1 Experimental condition for triaxial compression test series

\begin{tabular}{|c||c|c|c|c|c|c|}
\hline 試験名 & $\begin{array}{c}\text { 採取深度 } \\
(\mathrm{m})\end{array}$ & $\begin{array}{c}\text { 湿潣密度 } \\
\left(\mathrm{g} / \mathrm{cm}^{3}\right)\end{array}$ & $\begin{array}{c}\mathrm{P}_{\mathrm{C}}^{\prime} \\
(\mathrm{kPa})\end{array}$ & $\begin{array}{c}\mathrm{P}_{\mathrm{S}}^{\prime} \\
(\mathrm{kPa})\end{array}$ & $\begin{array}{c}\text { 初期含水比 } \\
(\%)\end{array}$ & $\begin{array}{c}\text { 初期的和度 } \\
(\%)\end{array}$ \\
\hline \hline UU1 & $8.7 \sim 9.1$ & 2.14 & 100 & 100 & 8.2 & 62.5 \\
\hline CU1 & $8.7 \sim 9.1$ & 2.08 & 178 & 178 & 8.8 & 59.2 \\
\hline CU2 & $13.2 \sim 13.9$ & 2.33 & 312 & 312 & 6.8 & 81.0 \\
\hline CU3 & $14.9 \sim 15.5$ & 2.41 & 394 & 394 & 5.9 & 90.9 \\
\hline CR2U1 & $13.2 \sim 13.9$ & 2.34 & 310 & 155 & 6.2 & 78.1 \\
\hline CR2U2 & $16.7 \sim 17.4$ & 2.33 & 400 & 200 & 5.8 & 72.9 \\
\hline CR4U1 & $14.9 \sim 15.5$ & 2.43 & 360 & 90 & 6.1 & 98.2 \\
\hline CR8U1 & $19.6 \sim 20.1$ & 2.27 & 500 & 63 & 11.5 & 98.6 \\
\hline CD1 & $12.1 \sim 12.9$ & 2.13 & 260 & 260 & 8.6 & 63.5 \\
\hline CR2D1 & $16.7 \sim 17.4$ & 2.37 & 400 & 200 & 4.5 & 67.7 \\
\hline
\end{tabular}




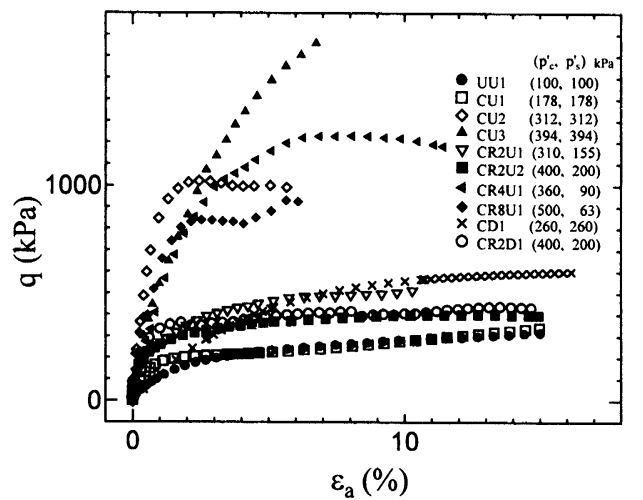

図ー2 三軸圧縮試験における応力ーひずみ関係

Fig. 2 Stress-strain relationships obtained by triaxial compression tests

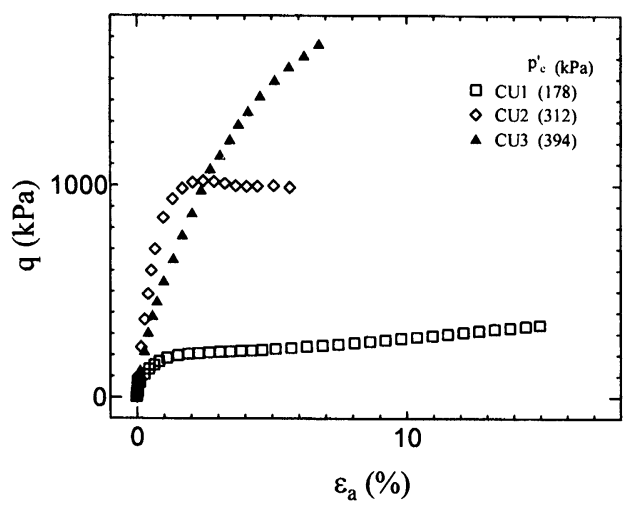

图一３応カーひずみ関係（CU, CD試験）

Fig. 3 Stress-strain relationships obtained by $\mathrm{CU}$ tests

図－4 は等方圧密圧力の近似したCU 3 とCR $4 \mathrm{U} 1$ お よびCR $8 \mathrm{U} 1$ 試験を比較したものである。CR 4 U 1 試 験はCU 3 試験の約 $2 / 3$, CR 8 U - 1 試験は約 $1 / 2$ 程度 まで強度が低下している。図-6は図-4に対応する過 圧密状態における非排水せん断強度 $\mathrm{S}_{\mathrm{u}}$ とせん断前の有効 応力 $\mathrm{p}$ と比 $\mathrm{S}_{\mathrm{u}} / \mathrm{p}$ 值である。デー夕数が少なく, 且つば らつきがあって大まかな数值でしかないが，図より算出 される傾きはおよそ0.64である。粘土についての既往の 多数の実験結果 ${ }^{14}$ が $0.77 \sim 0.86$ の範囲の值に入っている ことから, 蛇紋岩の吸水膨張による強度低下の割合は, 粘土に比べて大きいと言える。

図ー 5 は先行圧密圧力のほほ等しいCU 2 とCR 2 U 1 およびCR 2 D 1 試験を比較したものであり, 図から圧 密応力の除荷によって約 $1 / 2$ まで強度が低下したことが わかる。写真 - 1 はCR 2 U 1 試験の試験後の状態であ る。このように明膫なせん断面が現れることが多く，試 験後の典型的な例である。

図-7〜10は上記の応力〜ひずみ関係に対応する間隙 水圧〜ひずみ関係を示したものであり, CU 1 以外のす べての試験において，せん断の後半で負の間隙水圧が発 生して㧍り, 初期に間隙水圧が急激に増加した後, 比較 的ひずみの小さい段階で減少過程に移行している。図一

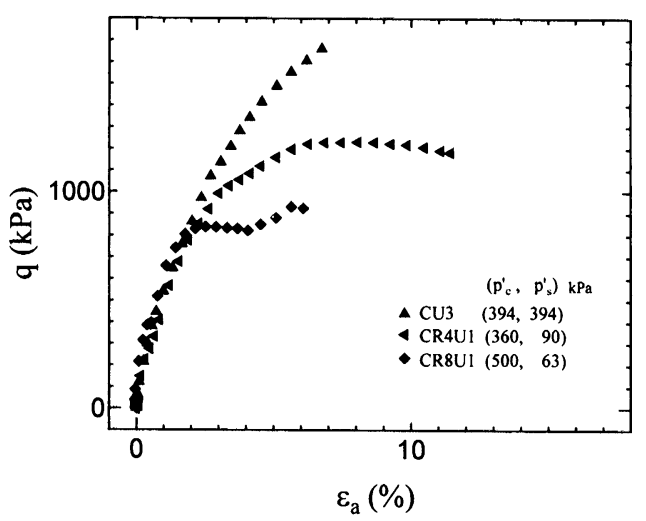

図ー4 応カーひずみ関係（CU 3, CRU試験）

Fig. 4 Stress-strain relationships obtained by $\mathrm{CU} 3$ and CRU tests

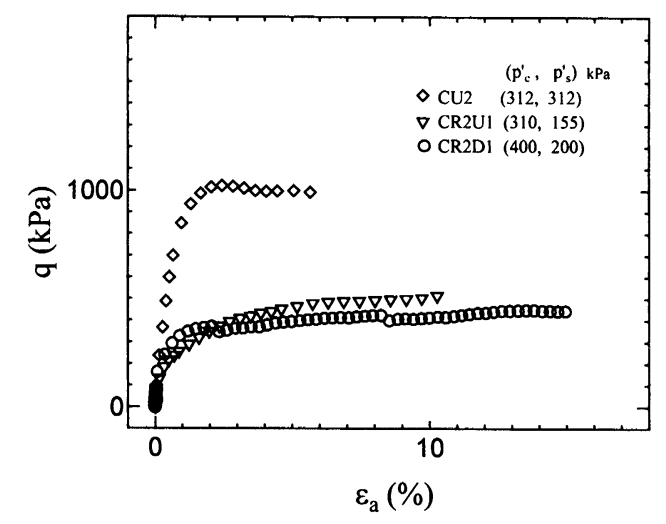

図一 5 応カーひずみ関係（CU 2, CR 2 U, CR 2 D試験）

Fig. 5 Stress-strain relationships obtained by CU2, CR 2 $\mathrm{U}$ and CR $2 \mathrm{D}$ test

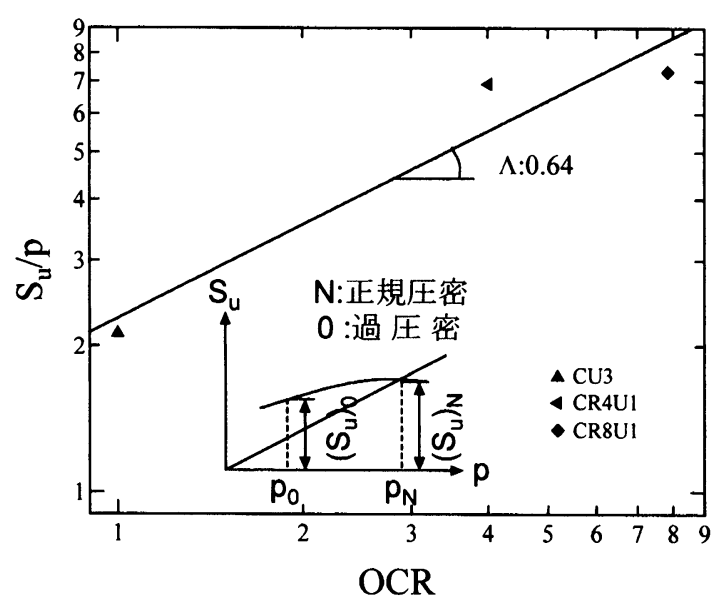

図一 6 過圧密状態における $\mathrm{S}_{\mathrm{u}} / \mathrm{p}$ 值

Fig. $6 \mathrm{~S} / \mathrm{p}$ value in overconsolidated state

8 は圧密応力の異なる 3 本のCU試験の比較であるが, CU $2, \mathrm{CU} 3$ 試験では負の間隙水圧が発生しており, 過 圧密粘土に類似した挙動を示している。図 - 9 はCU 3 とCR 4 U 1 , CR 8 U 1 試験の比較で, CR 4 U 1 とCR 8 U 1 試験はよく似た挙動を示した。CR 4 U 1 試験におい ては最も大きな負の間隙水圧が発生しており，これが図 


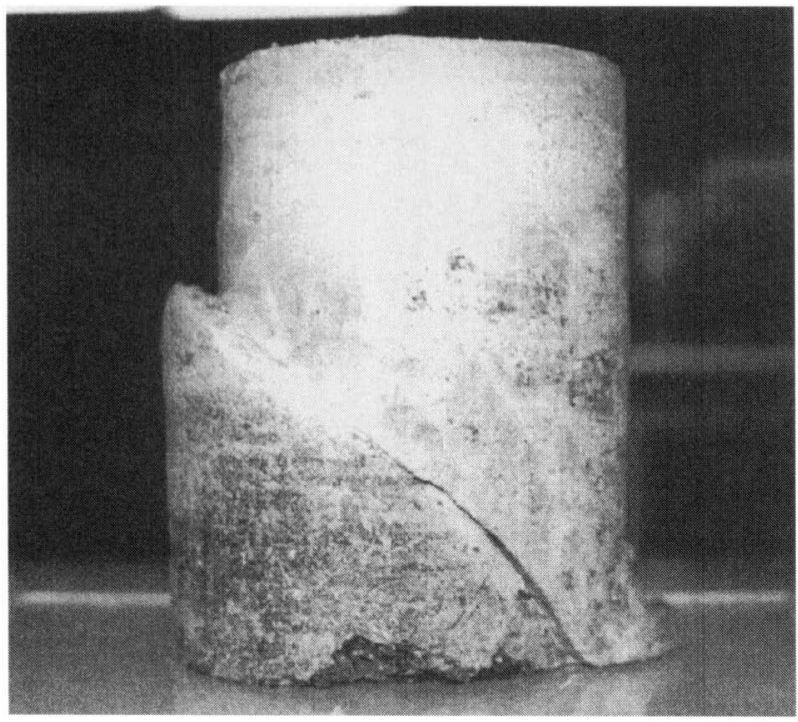

写真一 1 三軸圧縮試験における供試体の破壊状況

Photo 1 State of specimen after triaxial compression test

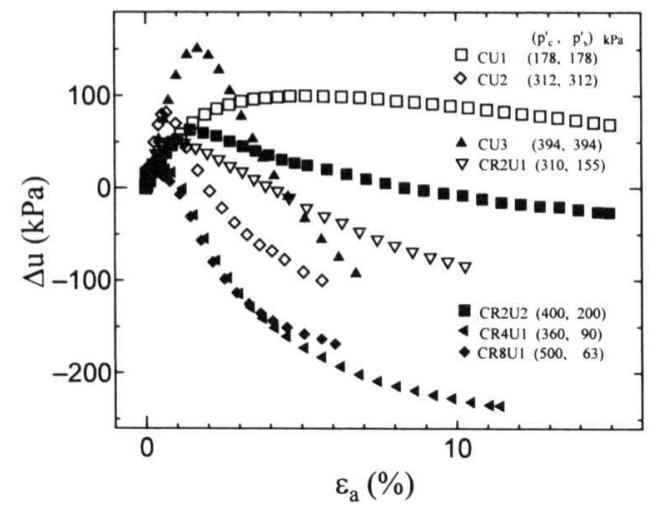

図ー7 非排水三軸圧縮試験における間隙水圧一ひずみ関係

Fig. 7 Pore water pressure vs. strain relationships obtained by undrained triaxial compression tests

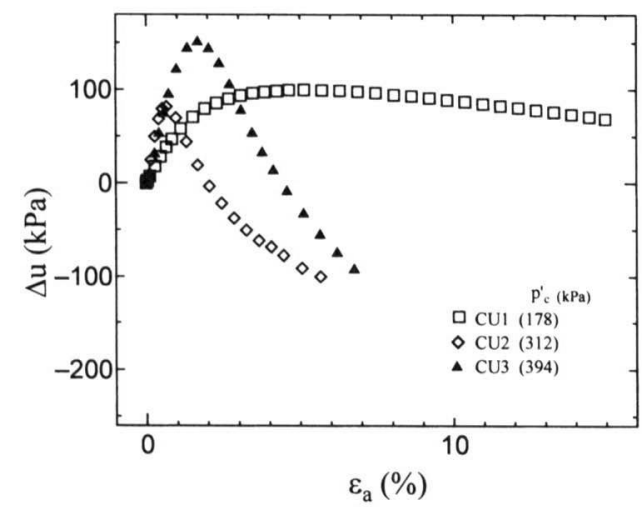

図一8 間隙水圧一ひずみ関係 (CU試験)

Fig. 8 Pore water pressure vs. strain relationships obtained by $\mathrm{CU}$ tests

- 4 における主応力差に反映されているものと説明でき 万。

図-11は排水せん断中の体積ひずみ $\left(\varepsilon_{\mathrm{v}}\right)$ 〜軸ひずみ 関係を示したもので，図からわかるように拘束圧の減少

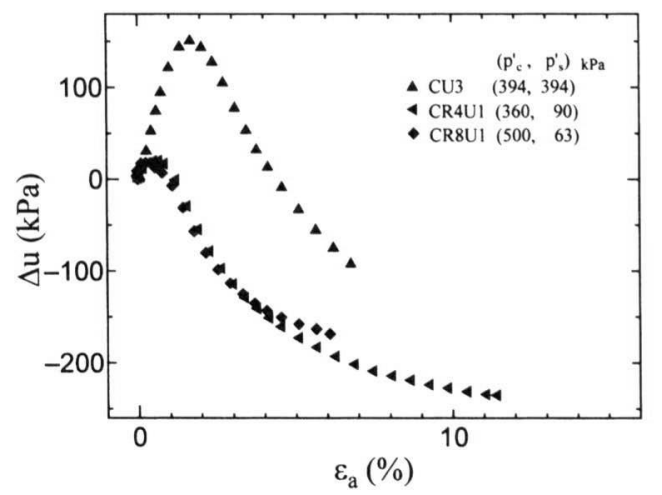

図－9 間隙水圧一ひずみ関係（CU 3，CRU試験）

Fig. 9 Pore water pressure vs. strain relationships obtained by CU 3 and CRU tests

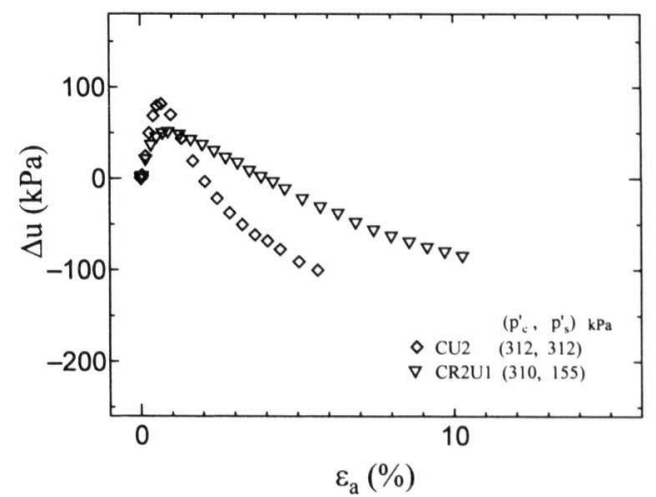

図－10 間隙水圧一ひずみ関係（CU2，CR 2 U試験）

Fig. 10 Pore water pressure vs. strain relationships obtained by CU 2 and $\mathrm{CR} 2 \mathrm{U}$ test

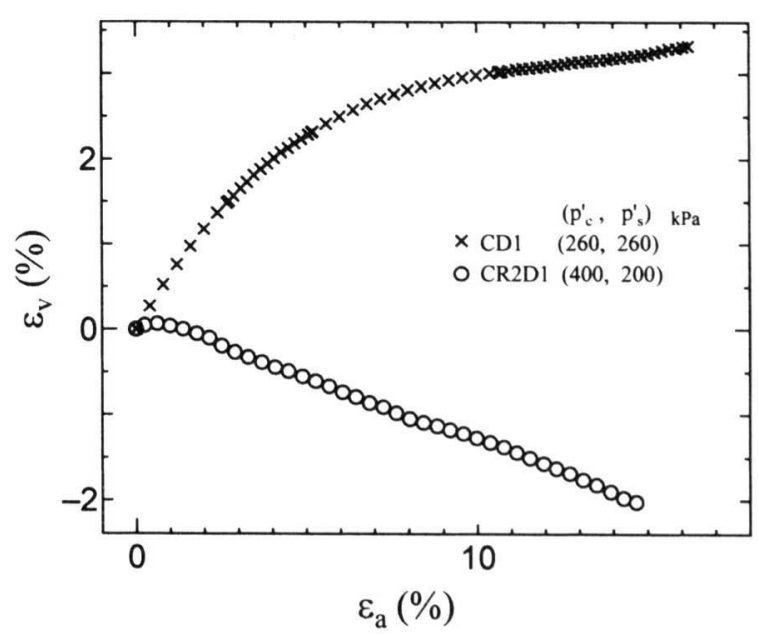

図-11排水三軸圧縮試験中の体積ひずみ一軸ひずみ関係

Fig. 11 Volumetric strain vs. axial strain relationships obtained by drained triaxial compression tests

によって体積膨張 $\left(\varepsilon_{\mathrm{v}}<0\right)$ 傾向が表われて吸水が生じ ていることが分かる。

(2) 有効応力径路およびせん断抵抗角

図－12は不撹乱供試体を用いたすべての試験について のせん断中の $\mathrm{q}-\mathrm{p}^{\prime}$ 面上の有効応力径路（ $\mathrm{p}^{\prime}$ は平均有効 主応力）を示したものであり,これを $\mathrm{q}_{\max }\left(=\left(\sigma_{\mathrm{a}}^{\prime}-\right.\right.$ 


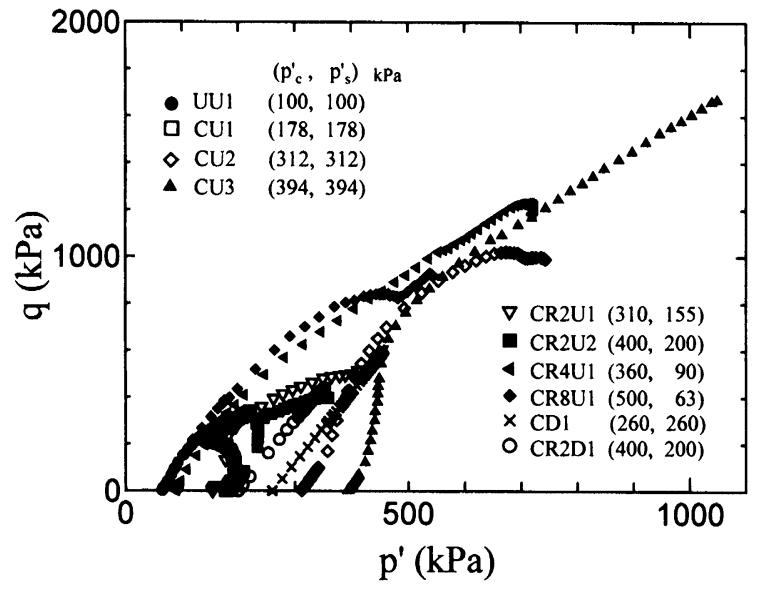

図一12 不撹乱蛇紋岩の三軸圧縮試験における有効応力径路

Fig. 12 Effective stress paths of undisturbed serpentinite during triaxial compression test

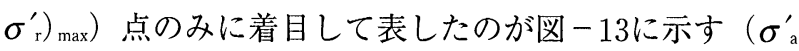
$\left.-\sigma_{\mathrm{r}}^{\prime}\right) / 2 \sim\left(\sigma_{\mathrm{a}}^{\prime}+\sigma_{\mathrm{r}}^{\prime}\right) / 2$ 関係で, 有効応力で評価すれば Mohr-Coulombの破壊基準で統一的な説明が可能である ことがわかる。本試験結果は不撹乱状態で採取された蛇 紋岩についてのものであるが, 図-13の直線の傾きと切 片から算出した強度パラメータは $\mathrm{c}^{\prime} \doteqdot 0 \mathrm{kPa}, \phi^{\prime}=31.6^{\circ}$ であり, 占冠地区の 2 箇所から採取した蛇紋岩風化粘土 (練り返し再構成試料) についての横田ら の)試験結果 $\left(\phi^{\prime}=30.3^{\circ}, 31.2^{\circ}\right)$ に近似しており，また北郷ら ${ }^{11)}$ 神居古潭帯の南北各地から採取した蛇紋岩粘土およびそ の細粒分調整試料について行った試験結果 $\left(\phi^{\prime}=30.0^{\circ}\right.$ 〜 36. $7^{\circ}$ ) の範囲とも一致している。

図ー14にCU試験における不撹乱蛇紋岩および再構成 蛇紋岩の有効応力径路の比較を示す。なお, 再構成蛇紋 岩粘性土は，不擋乱試料の試験後に粉砕したものを 425 $\mu \mathrm{m}$ ふるにかけ，その通過分を $200 \mathrm{kPa}$ で予圧密したも のである。データはともにせん断開始時の平均有効主応 力が $400 \mathrm{kPa}$ 程度の試験である。不擋乱蛇紋岩は正の夕゙ イレイタンシー傾向を示す結果, 右上がりの径路をた どっており, 再構成蛇紋岩の有効応力径路と大幅に異 なっている。その結果不擋乱蛇紋岩の主応力差の最大值 (軸力の計測能力の限界から $7 \%$ ひずみで打ち切って いる）は再構成蛇紋岩のそれ（15\%ひずみでの值）の約 4 倍となっている。

図－15にCU試験結果のみについての $\left(\sigma_{\mathrm{a}}^{\prime}-\sigma_{\mathrm{r}}^{\prime}\right) / 2 \sim$ $\left(\sigma_{\mathrm{a}}^{\prime}+\sigma_{\mathrm{r}}^{\prime}\right) / 2$ 関係の比較を示す。不擋乱蛇紋岩の $\phi^{\prime}$ は $30.3^{\circ}$, 再構成蛇紋岩の $\phi^{\prime}$ は $29.0^{\circ}$ とほとんど一致する。 図－14, 図一15に示した不攪乱と再構成蛇紋岩について の実験結果，および蛇紋岩風化粘土についての既往の研 究結果における $\phi^{\prime}$ の值がほとんど一致するということ を総合すると, 蛇紋岩が風化して粘性土化した場合, せ ん断抵抗角はほとんど变わらないが，ダイレイタンシー 特性が大きく変化する結果, 強度は不擋乱状態より大幅 に低下するといえる。

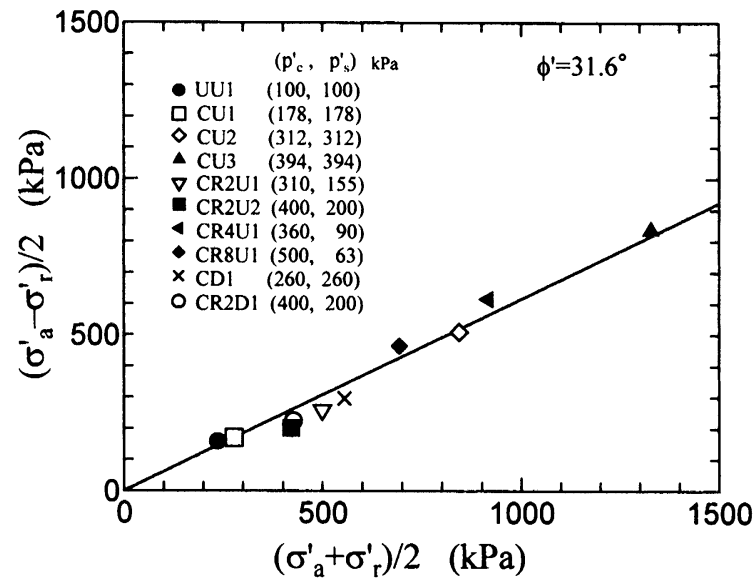

図-13 不撹乱蛇紋岩の三軸圧縮試験における $\left(\sigma_{\mathrm{a}}^{\prime}-\sigma_{\mathrm{r}}^{\prime}\right) /$ $2 \sim\left(\sigma_{\mathrm{a}}^{\prime}+\sigma_{\mathrm{r}}^{\prime}\right) / 2$ 関係

Fig. $13\left(\sigma_{\mathrm{a}}^{\prime}-\sigma_{\mathrm{r}}^{\prime}\right) / 2$ vs. $\left(\sigma_{\mathrm{a}}^{\prime}+\sigma_{\mathrm{r}}^{\prime}\right) / 2$ relationships obtained by triaxial compression test for undisturbed serpentinite

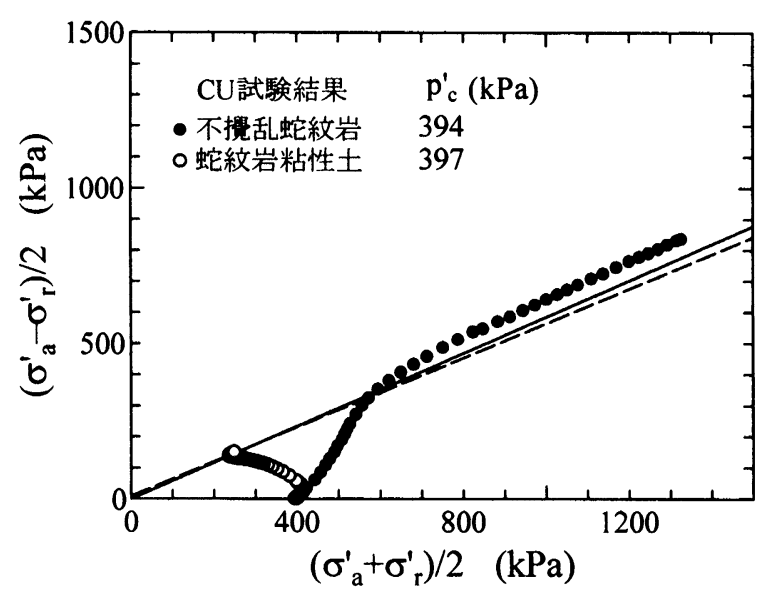

図-14 不撹乱蛇紋岩および蛇紋岩粘性土の有効応力径路の 比較

Fig. 14 Comparison of effective stress paths on undisturbed and reconstituted serpentinite

\section{4. 繰返し定圧一面せん断試験結果および考察}

繰返し一面せん断試験における供試体寸法は, 高さ 20 $\mathrm{mm}$, 直径 $60 \mathrm{~mm}$ である。残留状態のせん断抵抗角を求 める目的から，試料の中でも特に粘土化している部分を アクリル製コアチューブから切り出し，供試体成型用リ ングを押し込むようにして成型した。両面排水条件で, 所定の圧密応力まで載荷後， 3 t法によって圧密を打ち 切り, 定圧条件の下でせん断速度 $0.2 \mathrm{~mm} / \mathrm{min}$ で繰返し せん断を行った。繰返し回数は 5 ないし 6 回とし, 片振 幅は $6 \mathrm{~mm}$ ，せん断箱間隔は $0.2 \mathrm{~mm}$ である。

図－16に蛇紋岩の粘土化した部分の不擋乱試料と再構 成蛇紋岩粘性土についての繰返し定圧一面せん断試験結 果の比較を示す。不擋乱試料についてのピークせん断抵 抗角 $\phi_{\mathrm{p}}^{\prime}$ と再構成試料のピーク（=完全軟化状態）せん 断抵抗角 $\phi_{\mathrm{s}}^{\prime}$ とはほとんど一致している。これらの值は 前述の三軸試験結果と $3^{\circ}$ 程度の差はあるが, 不擋乱と 


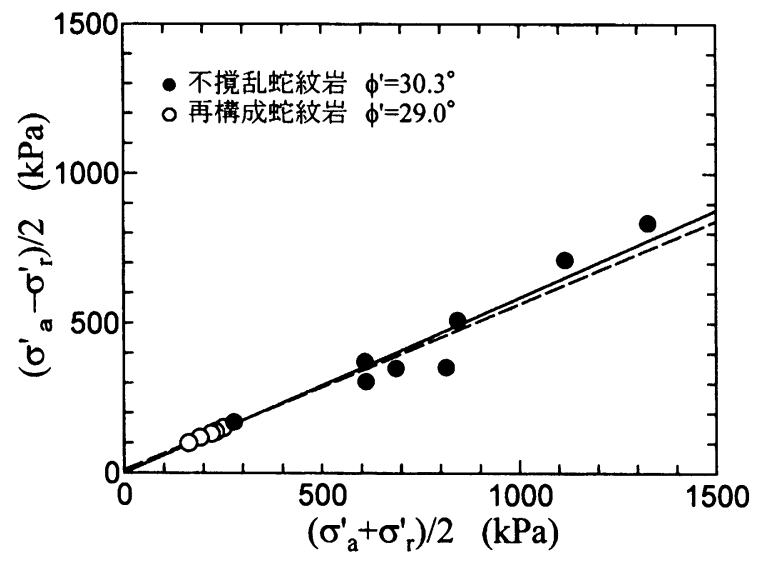

図ー15 不擋乱および再構成蛇紋岩における $\left(\sigma_{\mathrm{a}}^{\prime}-\sigma_{\mathrm{r}}^{\prime}\right) / 2$ $\sim\left(\sigma_{\mathrm{a}}^{\prime}+\sigma_{\mathrm{r}}^{\prime}\right) / 2$ 関係

Fig. $15\left(\sigma_{\mathrm{a}}^{\prime} \sim \sigma_{\mathrm{r}}^{\prime}\right) / 2$ vs. $\left(\sigma_{\mathrm{a}}^{\prime}+\sigma_{\mathrm{r}}^{\prime}\right) / 2$ relationships for undisturbed and reconstituted serpentinite

再構成試料の $\phi^{\prime}$ 関係は一致している。一方, 残留状態 のせん断抵抗角も不擋乱と再構成でほぼ一致し， $\phi_{\mathrm{p}}^{\prime}$ $\left(\phi_{\mathrm{s}}^{\prime}\right)$ から $\phi_{\mathrm{r}}^{\prime}$ への低下はおよそ $6^{\circ}$ である。横田ら ${ }^{7}$ は蛇 紋岩風化粘土の再構成試料について， $\phi_{\mathrm{p}}^{\prime}$ を三軸で， $\phi_{\mathrm{r}}^{\prime}$ をリングせん断試験で求めており，両者の差がおよそ $2^{\circ}$ と小さいことを報告している。本研究でも三軸試験 の $\phi^{\prime}=30.3^{\circ}$ （図-15）と, 繰返し一面せん断による $\phi^{\prime}{ }_{\mathrm{r}}$ $=27.7^{\circ}$ (図-16）との差をとれば，2.6であり，北海 道神居古潭帯における蛇紋岩のピークから残留状態への 強度低下は，比較的小さいことがわかる。

\section{5．葉片に沿う定圧一面せん断試験による実験結果}

蛇紋岩塊は地すべりの直接的な原因ではなく，単に移 動土塊を提供しているに過ぎないという指摘がある゙)。 しかしながら葉片状蛇紋岩が脆く崩れやすいことは実験 を通じて明白であり，新しい試みとして，剥離性の著し い蛇紋岩の葉片に沿う摩擦係数を求める目的で定圧一面

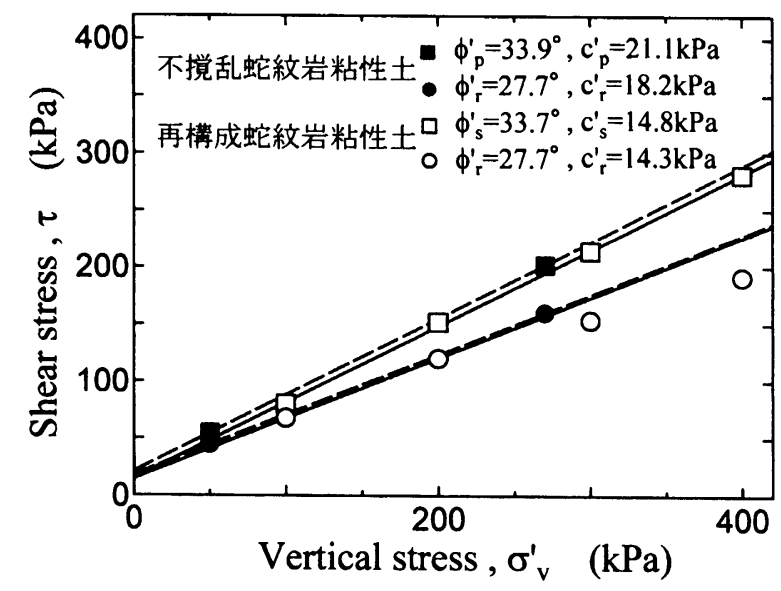

図ー16 定圧繰返し一面せん断試験におけるせん断応力一鉛 直応力関係

Fig. 16 Shear stress vs. vertical stress relationships obtained by constant pressure direct box shear tests
表－2 実験条件（一面せん断試験）

Table 2 Experimental condition for direct box shear test on foliated serpentinite specimen

\begin{tabular}{|c||c|c|c|c|c|}
\hline 試験名 & $\begin{array}{c}\text { 深度 } \\
(\mathrm{m})\end{array}$ & $\begin{array}{c}\sigma^{\prime} \mathrm{v} \\
(\mathrm{kPa})\end{array}$ & $\begin{array}{c}\text { 初期含水比 } \\
(\%)\end{array}$ & $\begin{array}{c}\text { 水浸 } \\
\text { 有無 }\end{array}$ & $\begin{array}{c}\text { 断面積 } \\
\left(\mathrm{cm}^{2}\right)\end{array}$ \\
\hline \hline SF01 & $16.65 \sim 16.75$ & 590 & 2.7 & $\bigcirc$ & 8.3 \\
\hline SF02 & $16.75 \sim 16.85$ & 395 & 4.0 & $\bigcirc$ & 9.9 \\
\hline SF03 & $16.85 \sim 16.95$ & 120 & 5.3 & $\bigcirc$ & 24.5 \\
\hline SF04 & $16.95 \sim 17.05$ & 127 & 3.7 & $\bigcirc$ & 30.8 \\
\hline SF05 & $17.35 \sim 17.55$ & 103 & 5.5 & $\bigcirc$ & 14.3 \\
\hline SF06 & $17.55 \sim 17.65$ & 337 & 7.1 & $\bigcirc$ & 21.8 \\
\hline SF07 & $15.88 \sim 17.05$ & 412 & 4.8 & $\times$ & 14.3 \\
\hline SF08 & $17.35 \sim 17.40$ & 360 & 3.5 & $\times$ & 6.8 \\
\hline SF09 & $17.15 \sim 17.25$ & 355 & 4.4 & $\times$ & 5.5 \\
\hline SF10 & $17.05 \sim 17.15$ & 117 & 4.1 & $\times$ & 8.4 \\
\hline
\end{tabular}

せん断試験を実施した。

\section{1 試験概要}

蛇紋岩の剥離面を含むと見られる岩片を選んで試験に 供することから，岩片試料の周りを石亩で固めた状態の ものを供試体とした。また試料の大きさも不定形であり， 断面積は試験後に求めることとなる。石胃の部分も含め た供試体直径は $75 \mathrm{~mm}$ ，高さは蛇紋岩の大きさによって それぞれ異なるが，約40〜60mmである。せん断箱間隔 はSF01〜SF06試験では $5 \mathrm{~mm}, \mathrm{SF} 07$ SF10試験では 1 $\mathrm{mm}$ ，せん断速度は $0.1 \mathrm{~mm} / \mathrm{min}$ である。なお $\mathrm{SF} 07$ SF 10 試験では最小の摩擦係数を求めるために予め試料を二 分し，せん断面をサンドペーパーで磨いたものを試料と した。試験条件を表一 2 に示す。

\section{2 供試体作成}

供試体を作成するために外径 $100 \mathrm{~mm}$ ，内径 $75 \mathrm{~mm}$ のア クリル円筒を用いた。アクリル円筒は上下に分かれてお

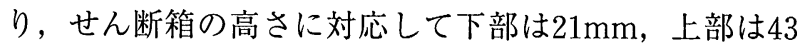
$\mathrm{mm}$ の高さであり，せん断箱に固定するためフランジを 設けてある。供試体の作成手順としては下部アクリル円 筒の中に石高を流し込み，固まりきる前にその上に試料 を置いて固定する。石亩の強度が影響しないよう，試料 の周り，上下せん断箱の間にグリースを満たす。その後 上部アクリル円筒を置き, 試料が隠れる程度まで石高を 流し込んで供試体の完成となる。また現場の状態に近づ けるため，SF01〜SF06試験では予め石高の上部に小孔 をあけ試料に蒸留水を供給させて試験を行った。SF07 〜SF10試験で蒸留水を供給しなかった理由は，磨いた せん断面をなるべく乱さないためである。なお石高を固 める時間を 24 時間，蒸留水を供給する時間も24時間とし た。これを試験前にアクリル円筒ごとせん断箱にセット し試験を行う。せん断箱と供試体概要を模式的に図 -17 に示す。

\section{3 試験結果と考察}

岩片試料をそのまま試験に供したSF01〜SF06試験と， 予めせん断面を磨いたSF07〜SF10試験結果のせん断応 力〜水平変位関係をそれぞれ図 - 18(a)および(b)に示した。 


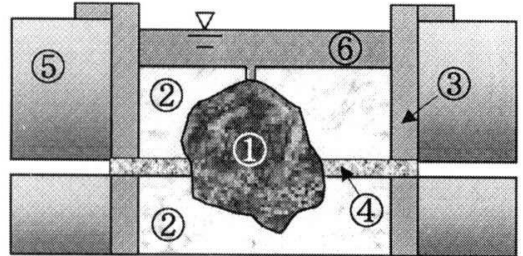

(1) 蛇紋岩

(2) 石膏

(3) アクリル

(4) グリース

(5) せ九断箱

(6) 蒸留水

図一17 葉片に沿う一面せん断試験のせん断箱と供試体概要

Fig. 17 Outline of shear box and foliated serpentinite specimen for the direct shear test along its foliation

実験の性格上，本来ばらつきの少ないデー夕を望むべく もないが，図に示すように他と大きく異なる傾向を示す ものもある。図一19は, 図-18に示したせん断応力〜水 平変位関係におけるピーク時のせん断応力〜鉛直応力関 係を示したものである。四のプロットにあたり，図-18 に揖ける挙動が他と異なる傾向を示すSF01，SF02およ びSF07を除いても， $\phi_{\mathrm{d}}$ の評価が大きく異なることはな いとの判断から，特にこれらのデー夕を除外することは しなかった。図ー19に示すように, SF01〜SF06試験結 果から $\phi_{\mathrm{d}}=34.3^{\circ}$ (図中，実線）で図－13および図 -16 に近似する結果が得られた。蛇紋岩の葉片状の部分は実 際には滑らかなものであり，この面がせん断面と一致す ればもっと小さな值になると思われる。しかし，滑らか ではあるが水平とは言い難い葉片部分を強制的にせん断 しているので，実駼結果は予想外に大きな $\phi_{\mathrm{d}}$ 示したも のと思われる。一方，サンドペーパーで磨かれた状態の せん断面についてのSF07〜SF10試験のせん断応力〜鉛 直応力関係から蛇紋岩の葉片に沿う最小のせん断抵抗角 として $\phi_{\mathrm{d}}=6.5^{\circ}$ (図中, 破線) が得られた。すなわち， 蛇紋岩のせん断抵抗角は $6.5^{\circ} \sim 34.3^{\circ}$ の範囲にあるが, 葉片に沿ったせん断が行われれば，その值は最小值すな わち $6.5^{\circ}$ 前後の值に近づくと考えられる。

\section{6. 各種せん断試験結果のまとめ}

前章までに示したように，本研究では不㩭乱状態揖よ び練返し再構成試料についての圧密非排水三軸圧縮試験, 粘土化した状態の不缷乱試料についての繰返し一面せん 断試験，さらに不䚓乱蛇紋岩の葉片に沿う一面せん断試 験を実施した。これらの試験結果を総合すると，以下の ようにまとめることができる。

通常の方法で実施された三軸試験や繰返し一面せん断 試験から得られる蛇紋岩および蛇紋岩風化粘性土のせん 断抵抗角 $\phi^{\prime}$ はそのイメージからかけ離れた大きな值 $\left(\phi^{\prime}=30^{\circ}\right.$ 前後 $)$ を示す。しかし, 粘土化した蛇紋岩の場 合，負のダイレイタンシーを示す結果，非排水せん断強 度は不摚乱状態に比べて極めて小さい。したがって，せ ん断強度の適切な評価のためにはダイレイタンシー特性 の把握が不可欠である。一方, 不摚乱状態でも葉片に沿 うすべり面が発生するようなせん断条件の場合には中'

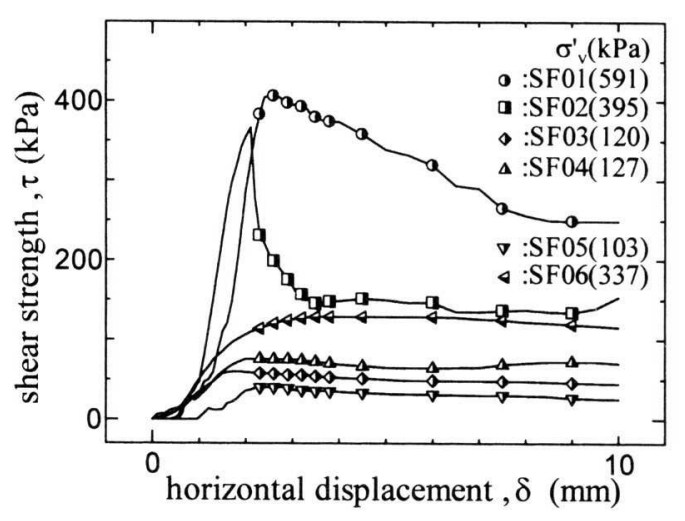

(a)

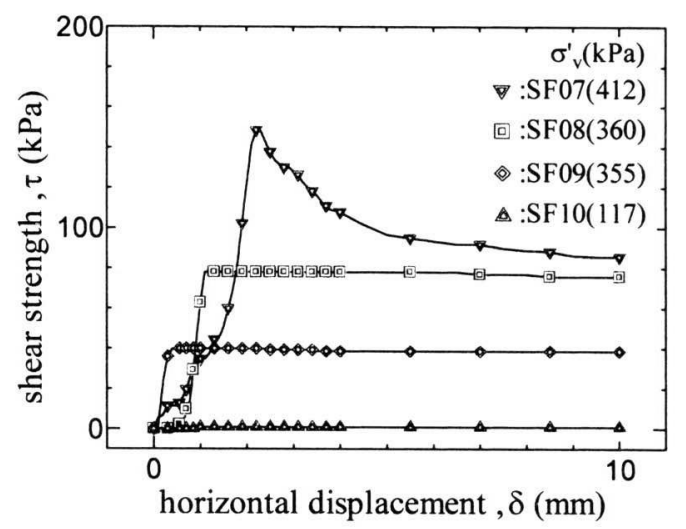

(b)

図一18 葉片に沿う一面せん断試験におけるせん断応力一水 平変位関係

Fig. 18 Shear stress vs. horizontal displacement relationships for foliated serpentinite

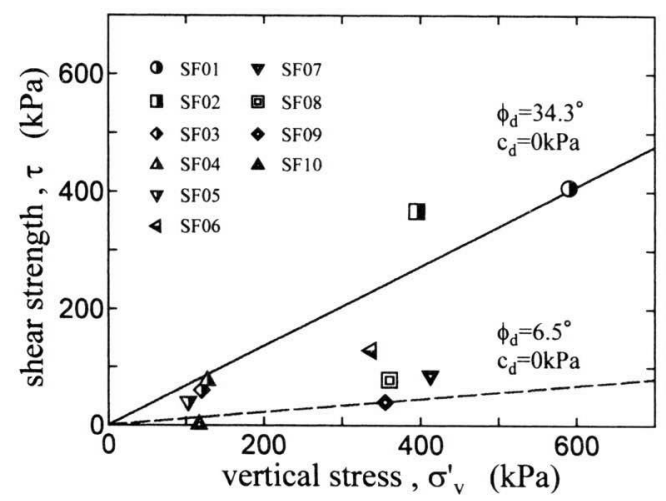

図ー19 葉片に沿う一面せん断試験におけるせん断応力一鉛 直応力関係

Fig. 19 Shear stress vs. vertical stress relationships for foliated serpentinite

そのものが大きく低下し，最も小さい場合で $\phi^{\prime}=6^{\circ}$ 前 後の值をとる。次章で述べるようにスレーキングによっ て容易に固結力が低下することとあわせて考えると，設 計にあたっての最悪の条件として，葉片に沿うすべりが 生じる場合のせん断抵抗角の大きさを考虑に入れておく 必要があると考えられる。 


\section{7. スレーキング試験}

蛇紋岩のスレーキングの度合いを調べるために，不摚 乱蛇紋岩の中から硬質な岩片を選んで，日本道路公団の 基準（KODAN111）による乾湿繰返し方法によってス レーキング試験を実施した。自然含水状態(含水比 $6.7 \%$ ) の岩石試料の質量を測定し，24時間水浸させ， $90^{\circ} \mathrm{C}$ の温 度で標準48時間炉乾燥する。乾燥した試料をデシケータ 内で室温まで冷まし，その質量を測定した後再び水浸す る操作を10回繰り返すことになっているが，1 回目炉乾 燥後の水浸における吸水量は8.1\%で，この水浸におい て試料は崩壊したので試験終了となった。試料は蒸留水 を入れた直後に崩壊し始め, 1 日後にはほとんど細粒化 した。このことより蛇紋岩のスレーキングの度合いは顕 著であり，自然状態では硬質であっても水の影響により 容易に崩壊し固結力が低下することが確認された。

\section{8. 膨潤圧試験}

蛇紋岩地帯でのトンネル工事において，過去に膨張性 土圧の発生により難工事を強いられたという報告 ${ }^{15)}$ があ る。その原因として(1)構成鉱物の吸水澎張，(2)地層の破 壊と塑性変形，(3)潜在応力の解放の 3 つが考えられてい る ${ }^{15)}$ 。ここでは前述のMB法によりスメクタイトの存在 が確認されていることから，(1)に着目して膨潤圧の測定 を行った。試料はX線回折に用いた試料 I , II と同じボー リング孔（2ヶ所）で採取された試料の $425 \mu \mathrm{m}$ ふいい 通過分であり，以下それぞれ試料 $\mathrm{A}$ ，試料Bとする。供 試体寸法は直径 $60 \mathrm{~mm}$ ，高さ $20 \mathrm{~mm}$ とし，ステンレス製 の压密リングを締固め容器にセットして, 乾燥粉末試料 を静的に締固めることにより作製した。実験条件を表一 3 に示す。なお，試料の初期状態は乾燥粉末状態である。

\section{1 試験装置}

試験には定ひずみ速度圧密試験用の載荷装置を用いた。 供試体をセットしたのち後述の大きさの初期載荷を行い, 載荷フレームを固定した状態で試験開始と同時に浸水さ せ，ロードセルにより膨潤圧を測定する。但し本実験に おいて最大の場合で $0.1 \mathrm{~mm}$ の軸方向変位が観測されて いる。初期載荷については, 締固め容器から取り出す際 に応力が一時解放されることから生じる供試体の膨張を 考虑して奉施した。

\section{2 試験結果と考察}

図 - 20(a)，20(b)に膨潤圧〜時間関係を示す。締固め応 力を 3 種類 $(3.5,6.3,10.2 \mathrm{MPa})$ に変えて実験を行 い, 初期載荷応力として本研究では試みにそれぞれ約 50 $\mathrm{kPa}, 100 \mathrm{kPa}$ として実験を開始した。図より締固め応力 が大きい方が膨潤圧も大きいが，試料A（SWA 1 ～SWA 6) と試料B（SWB 1 〜SWB 6 ）の挙動は明らかに異 なることがわかる。図ー20(a)においては締固め応力が等 しくても初期載荷応力の大きい方が膨潤圧は $20 \mathrm{kPa} \sim 40$ $\mathrm{kPa}$ ほど大きいのに対し, 図-20(b)ではピークの発現の 仕方に緩急の違いはあるが，膨潤圧のピークはほぼ等し
表－3 実験条件（膨潤圧試験）

Table 3 Experimental condition for swelling pressure test

\begin{tabular}{|c||c|c|c|c|}
\hline 試験名 & $\begin{array}{c}\text { 乾燥密度 } \\
\left(\boldsymbol{c} / \mathrm{cm}^{3}\right)\end{array}$ & $\begin{array}{c}\text { 締固め応力 } \\
(\mathrm{MPa})\end{array}$ & $\begin{array}{c}\text { 初期載荷 } \\
(\mathrm{kPa})\end{array}$ & $\begin{array}{c}\text { スメクタイト } \\
\text { 含直量(\%) }\end{array}$ \\
\hline \hline SWA1 & 1.63 & 3.5 & 51 & 4.3 \\
\hline SWA2 & 1.63 & 3.5 & 100 & 2.9 \\
\hline SWA3 & 1.71 & 6.3 & 49 & 2.9 \\
\hline SWA4 & 1.71 & 6.3 & 100 & 4.3 \\
\hline SWA5 & 1.79 & 10.2 & 52 & 4.3 \\
\hline SWA6 & 1.79 & 10.2 & 101 & 4.3 \\
\hline SWB1 & 1.65 & 3.5 & 51 & 8.6 \\
\hline SWB2 & 1.65 & 3.5 & 100 & 8.6 \\
\hline SWB3 & 1.74 & 6.3 & 52 & 10.0 \\
\hline SWB4 & 1.74 & 6.3 & 100 & 11.4 \\
\hline SWB5 & 1.80 & 10.0 & 55 & 10.0 \\
\hline SWB6 & 1.83 & 10.0 & 101 & 8.6 \\
\hline
\end{tabular}

い。また，条件の等しい試験でも試料Bより試料Aの方 が膨潤圧は大きい。表一 3 よりスメクタイト含有量は, 試料Aが $2.9 〜 4.3 \%$ のに対し，試料Bは $10 \%$ 前後と含 有量が多い。このことから，スメクタイト含有量の多璂 が必ずしも発生膨潤圧の大きさに直接結びついていない ことが分かる。

筆者らは緩衝材としてのベントナイト・珪砂混合士の 力学特性の研究に関連してベントナイト混合率を 30，50，70\%に変えた試料についての膨潤圧測定を行っ ている ${ }^{16)}$ 。その結果によれば，ベントナイト混合率の増 加とともに膨潤圧が直線的に増加し，混合率 $20 \%$ の増加 に対して150〜200kPaの膨潤圧の増加がみられた。蛇紋 岩についての膨潤圧の測定結果が前述のような傾向を示 したのは，試料A，Bともにスメクタイト含有量が予想 外に低かったことによるものではないかと考えられる。

\section{9. 結 論}

北海道神居古潭帯に産出する蛇紋岩について各種室内 試験を行った結果，以下の結論を得た。

(1) X線回折およびメチレンブルー吸着法による測定 結果から，スメクタイト含有量は比較的少なく，ま た，膨潤圧の大小が必ずしもスメクタイト含有量と 直接的な関係にはないことが分った。

(2) 圧密非排水（CU）三軸圧縮試験におけるせん断 抵抗角は不擋乱蛇紋岩および蛇紋岩粘性土ともほぼ 一致し， $30^{\circ}$ 前後の值をとる。この值はまた，蛇紋 岩風化粘土についての既往の研究結果とも一致する。 したがって，これらを総合すると蛇紋岩のせん断抵 抗角そのものは練り返しや風化の影響を受けにくい といえる。しかし，蛇紋岩粘性土の非排水せん断強 度はダイレイタンシー特性の違いから, 不攪乱蛇紋 岩よりも大幅に低下する。

(3) CU試験および繰返し一面せん断試験の結果, 蛇 紋岩のピークせん断抵抗角 $\phi^{\prime}{ }_{\mathrm{p}}$ は不擋乱, 再構成に 


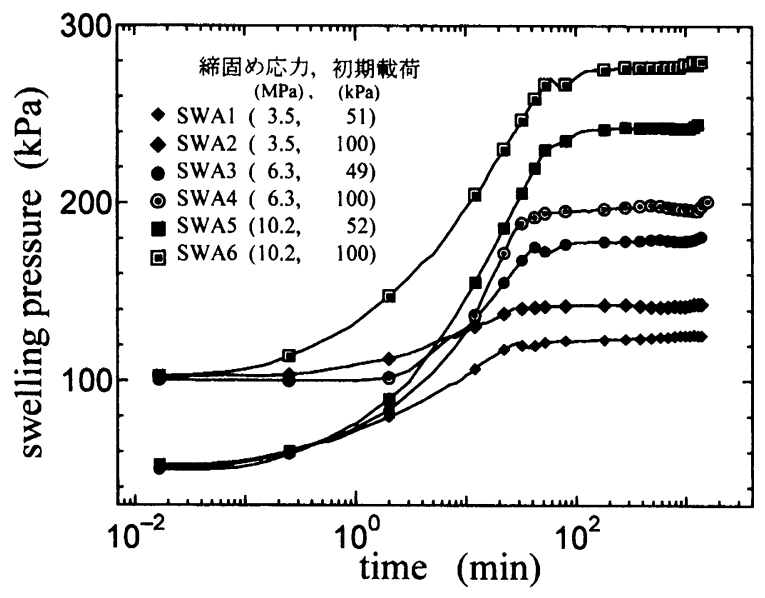

図一20(a) 膨潤圧一時間関係（試料A）

Fig. 20(a) Swelling pressure vs. time relationships for sample A

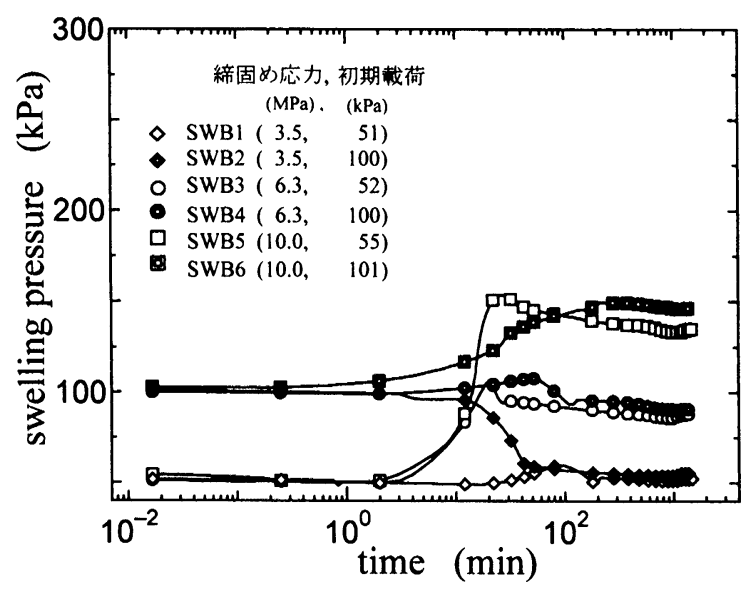

図一20(b) 膨潤圧一時間関係（試料B）

Fig. 20(b) Swelling pressure vs. time relationships for sample B

よらず， $31 \pm 2^{\circ}$ 程度の值をとり，残留状態のせん

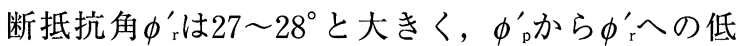
下は比較的小さい。

（4）葉片に沿って強制的にせん断を生じさせる目的で 実施した一面せん断試験結果から得られた蛇紋岩の せん断抵抗角は $34.3^{\circ}$ であるが，予め葉片に沿って 二分し，試料の表面を磨いた状態での試験結果から 得られたせん断抵抗角は $6.5^{\circ}$ であった。

（5）葉片状蛇紋岩は水の供給によって容易にスレーキ ングを起こし崩壊しやすい。

(6) 上記(2) (4)のように，通常のせん断試験方法に よって得られる蛇紋岩および蛇紋岩風化粘性土のせ ん断抵抗角 $\phi^{\prime}$ はそのイメージからかけ離れた大き な值を示す。しかし，粘土化した蛇紋岩の非排水せ ん断強度そのものは不擋乱状態に比べて極めて小さ く，また，不擋乱状態でも葉片に沿うすべり面が発 生するようなせん断条件の場合には市年のものが 大きく低下する。

（7）本研究で実施した各種せん断試験およびスレーキ
ング試験の結果を総合して考えると，現場の施工条 件として排水の重要性は言うまでもないが，設計に あたっての最悪の条件として，葉片に沿うすべり面 を想定したせん断抵抗角の大きさを考慮に入れてお く必要があると考えられる。

\section{謝辞}

本研究に用いた蛇紋岩試料は日本道路公団北海道支社 より提供を受けたものである。また，本報告をまとまる にあたり，X線回折分析において北海道大学大学院工学 研究科の米田哲朗先生, ならびに小野修司先生のご指導 を得た。ここに記して深甚なる感謝の意を表します。

\section{参考文献}

1 ）野地正保（1978）：蛇紋岩と土木工事（第 1 報）一蛇紋岩と蛇 紋岩化作用一, 北海道開発局土木試験所月報No. 342, pp. 10 $-19$.

2 ）矢田部龍一, 横田公忠, 八木則男, 野地正保 (1997)：蛇紋岩 地すべりの発生機構に対する検討, 地すべり, 第34巻, 第 1 号, pp. 24-30.

3 ）梅津一晴（1995）: 蛇紋岩の土木地質的一検討, 応用地質 36 巻 5 号, pp. $46-55$.

4 ）横田公忠, 矢田部龍一, 八木則男 (1998）: 蛇紋岩地すべりに 対する鉱物学的一考察, 地すべり, 第 35 巻, 第 3 号, pp. 15 $-23$.

5 ）野地正保（1978）：蛇紋岩と土木工事（第 2 報）一蛇紋岩地帯 の陸水の水質 -, 北海道開発局土木試験所月報, No. 342, pp. $1-22$.

6 ）野地正保（1984）：蛇紋岩と土木工事（第 3 報）－神竜幹線導 水トンネルー, 北海道開発局土木試験所月報, No. 378, pp. 1 $-9$.

7 ）横田公忠, 矢田部龍一, 八木則男 (1995)：蛇紋岩の風化粘性 土の強度特性, 土木学会論文集, No. 529/ III - 33, pp. 155 163.

8 ）横田公忠, 矢田部龍一, 八木則男 (1996)：蛇紋岩の風化粘性 土に起因した切土のり面の崩壊に関する一考察，土木学会論 文集, No. 541/III-35, pp. 57-65.

9 ）横田公忠, 矢田部龍一, 八木則男 (1997)：蛇紋岩地带の地す ベりの発達に及ぼす粘土鉱物とせん断強度の影響, 土木学会 論文集, No. 568/III-39, pp. 125-132.

10）北郷 繁（1973）：蛇紋岩の土質工学的性質，第 8 回土質工学 研究発表会講演集, pp. $65-72$.

11）北郷 繁, 寺崎靖則, 掛橋隆睛, 田中洋行（1974）: 蛇紋岩の 土質工学的性質 (第 2 報), 土質工学会北海道支部技術報告集. pp. $33-41$.

12）三田地利之，和智真太郎，松永卓也（1999）：不摚乱状態で採 取された蛇紋岩の吸水膨張による強度変化，地盤工学会北海 道支部技術報告集第39号, pp. 183-188.

13）和智真太郎，三田地利之，川口貴之（2000）: 蛇紋岩粘性土の 強度 - 变形特性, 地盤工学会北海道支部技術報告集第 40 号, pp. $173-180$.

14）社地盤工学会（2000）: 土質試験の方法と解説 - 第 1 回改訂 版一, pp. 496-497.

15）喜田大三，辻 博和（1973）：ずい道工事における風化じゃ紋 岩の土質化学的研究, 第 8 回土質工学研究発表会講演集, pp. $69-72$.

16）小松賢司, 三田地利之，戎 剛史，谷村匡哉（2003）：各種室 内試験によるベントナイト・珪砂混合土の力学特性，第58回 土木学会年次講演会 (投稿中).

（原稿受付 2003 年 3 月 11 日，原稿受理2003年 9 月 1 日） 